\section{THE DENTIST IN THE UNITED STATES NAVY.*}

RICHARD GRADY, M.D., D.D.S.

Resident Dentist, Lnited states Naval Academy. ANXAPOLIS, MD.

The title of this paper is ambitious but not correct. In the Nary there is no such grade as dentist, as there is no authority of law under which such an appointment can be made, except for service at the United States Naval Academy.

The need of dental services in the Army and Navy was first urged fully fifty years ago. The matter had been laid before Congress several times previous to the Spanish-American War, but without any action being taken. A dentist was appointed at the U. S. Naval Academy with the rank of assistant surgeon, and that was all that had been done in the matter, except that at the opening of the Civil War all army surgeons were supplied with forceps.

It is difficult to state with precision at whose suggestion the initial steps were taken which culminated in legislation creating a dental corps in connection with the 7 . S. Army service, but in 1898 when the National Association of Dental Examiners met in - Washington, 1). C., I prepared two resolutions signed by Dr. 'T. S'. Waters of Baltimore and mrself for adoption, one looking to the unification of state dental legislation and the other to the appointment of dentists in the U. S. Army and Navy.

To show the position assumed at that time (when I had not the slightest expectation of becoming dentist at the U. S. Naval Academy) the latter is quoted:

Wukneas, Congress adjourned without action on the bill introduced (May 27, 1898) to establish a branch of the Me: ical Department, to be known as the Dental Corps; therefore be it

Resolved: (1) That it is the sense of this meeting that the matter should be taken up again, with the hope that another effort will result successfully, and that the dentists of the country, by letters, and the organized societies, by resolutions, should give evidene to their representatives in Congress that they do sincerely desire such a law.

Resolved: (2) That a committee of five be appointed to inaugurate steps looking to the speedy action of all dental organizations, cordially endorsing the employment of qualified dental surgeons in the Army and Navy.

Resolved: (3) That this meeting notes with pleasure, that while various attempts were made throughout the country, notally by the Missouri State Dental Association (which Wals llie first to endorse the bill referred to) and the Chicann Dental Society, the issue was brought to a practical and suceessful result, at least so far as the forces now in the Phillippines are concerned, by the appointment of a graduate of the dental department of the University of California and two assistants, to serve with General Merritt's Army.

Sooner or later positive action must be taken by Congress on the question of dentists in the Navy. Congress has already recognized the value and need of dental services in the army by providing for thirty-one contract dental surgeons and appropriating $\$ 5 \%, 960$ for their salaries this year, the addition to the thirty heretofore authorized being for the U. S. Military Academy. I shall conclude this paper with the substance of the latest discussion of the question of dental surgeons for the Navy in the House of Representatives, February, 1907, so ably led by the Hon. Robert G. Cousins of

* Fead in the section on Stomatology of the Amelican Medical Assocition, at the Fifty eighth Anumal Session. held at Atlantic City. June, 1907.
Iowa, of the Committce on Taval Affairs, which hat unanimously recommended the bill. America is the only nation which has made anything like adequate provision for the dental care of its soldiers. The dental force in the South African War (according to the Iondon Lancet) was "one dental attendant to this British Army of about 200,000 officers and men."

Every valid argument used in favor of dentists in the Army may be urged with equal force in behalf of dentists in the Navy (at naval stations, at least). As the U. S. Army has its dental surceons, the Navy certainly needs the same adjunct to its medical staff. Really the naval man has fewer opportunities than the military to secure the services of a civilian dentist on account of his environment.

If the services of the dental corps of the Army, as officially published, have almost immediately relicved many cases that were previously carried for several days on the company's sick report, why could not a similar statement be made of the Nary, under like conditions, where the record gives 268 dars as the total number of sick days from two cases of dental caries, and the daily average of all cases under treatment at the same time as only 7.36 ?

If public sentiment is so aroused as to demand enlightened and adequate dental treatment for the officers and enlisted men of the Navy, it will be found feasible for Congress to meet the demand. Socrates is credited with having said: "The state is a great and noble steed, who is tardy in his motions, owing to his great size, and requires to be stirred into life; hence a gadfly is necessary to fasten on the state to arouse, persuade and reproach, lest the state may fall asleep."

Who are so competent to know the requirements of the naval service as those who are familiar with it? Resides, why should the Secretary of the Navy and the Surgeon Gencral be criticised for recognizing the olstacles which surround the launching of a new line of service-a Dental Corps in the Navy-an innovation contrary to established policy? The only hope for passing a bill to add a corps of dental surgeons to the Bureau of Medicine and Surgery of the Nayy is by cooperating with these officials and not by abusing them.

The text of the bill offered Feb. 14. 190\%, as an amendment to the Naral Appropriation Bill, consists of one paragraph which follows, and its discussion shows how it is viewed by members of Congress when called on to act. while the objections made should be borne in mind in any contemplated logislation submitted to the next Congress from any source:

Dental surceons for the Nary: That the President be. and he is hereby, authorized to appoint dental surgeons to serve the officers and enlisted men of the Navy and Marine Corps, not to exceed thirty in all. Said dental surgeons shall have the rank and compensation of acting assistant surgeons in the Navy; shall be graduates of standard dental colleges, trained in the several branches of dentistry; of good moral character and professional standing, and shall pass a physical and professional examination; and their appointment shall be for a term of years, and revocable at the pleasure of the President, and the sum of $\$ 50,000$, or so much thereof as may be necessary, is hereby appropriated for that purpose.

The points considered are:

1. The appointment of dental surgeons should be for a term of years and revocable at the pleasure of the President.

2. If we are to have dental surgeons as officers in the Navy they will have to go on the retired list and be arpointed for life the same as other officers. 
3. In reference to the desirability of having dental surgeons in the Navy, certainly some provision ought to be made for them.

4. Does the Committee on Naval Affairs believe that it can create any commissioned officers in the Navy who will not be appointed for life and put on the retired list within a very short time by law?

5. The bill does not create a dental corps; it simply hires a number of men, dentists of good standing, who shall have the rank of assistant surgeons, the right to discharge them at will being left to the President.

6. The committee in providing for dental surgeons discriminates against them. An assistant surgeon of the Navy must be appointed by the President and confirmed by the Senate. Now it is proposed to give the same rank to. a dental surgeon, but his appointment is not confirmed by the Senate; he is appointed for a term of years-no one knows whether it be for one year or fifty years-but at the pleasure of the President. Certainly if we are going to provide these surqeons in the Navy we ought to provide them on exactly the same basis as other assistant surgeons.

7. An assistant surgeon is a commissioned officer.

8: The Navy probably needs dental surgeons as much as the Army, and it has worked admirably in the Army. Providing dental surgeons in the Navy ought to be on the same basis as the dental surgeons in the Army. The Army has no commissioned dental surgeons; they are contract dental surgeons. This amendment proposes that they shall have the rank of assistant surgeons, revocalle at the pleasure of the President. That changes the law and would get rid of an officer without a courtmartial. The President, unless some charge was made against a man, would undoubtedly leave the assistant surgeon in until the time of retiring and retire him with rank and pay of assistant surgeon.

9. Both arms of the service should be alike so that we shall not be constantly hammered to raise one to the level of the other.

10. Have contract dental surgeons until the time comes when we can report a bill outsile an appropriation bill to deal with this question as it should be, and put these men on the basis they are entitled to have in accordance with the dignity of their profession.

11. If he is a contract dental surgeon the department would have the right to remove him without going to the President. The chief medical officer is the proper one. if he is to be removed for incompetency.

12. The government ought to provide for the needs of the Navy along this line. Do not favor any provision that authorizes the President or any other officer arbitrarily to remove any officer at his pleasure. The tendency of that system is to make flunkeys and sycophants of every man in the service subject to that power.

13. Clearly the intention is to make them contract dental surgeons. The Army dental surgeon is a contract dental surgeon.

14. The army contract does not run for any definite time. The medical department of the Army has charge of that. It would be better to put the power of removal in the medical department of the Navy.

15. Strike out the word "rank" and provide for the pay of an assistant surgeon of the Navy, then make him subject to removal by the Surgeon General of the Navy, and all will be accomplished that can be in this bill of putting the two arms of the service on exact equality.

16. You could not secure competent dental surgcons to go away and remain for a cruise of a number of years. You would cripple the efficiency of this proposition if you made it impossible to get dental surgeons who could remain away for a term of years, which you could not do if you should merely make them contract surgeons.

17. The dental surgeon of the Army, when he makes the contract, surrenders his practice absolutely. He goes to Alaska, to the Philippine Islands, or to Cuba if his regiment is there. He is employed simply as a contract surgeon without any term of years. If he is competent he will stay as long as he is able to do his work.

18. What class of men are obtained in the Armystudents, beginners? No, an excellent class of men. But every one of them now asks for a commissioned rank. Do not want to see one branch of the service get a commissioned rank and have thirty odd men the other way in another branch of the service.

The following are extracts from the report of the Committee on Naval Affairs which accompanied Hon. Robert G. Cousins' remarks :

1. At present there is no provision of law under which the Department can employ dental surgeons except one for service at the Naval Academy.

Surgeon-General Rixey informs this committee that the dental operations performed by the hospital stewards "are limited to simple procedures and urgent cases," that "this arrangement is a makeshift unsatisfactory to the burcau," that "the necessity of the care of the teeth of the enlisted men existed and its importance to the health of the Navy is appreciated," and therefore this makeshift was resorted to "until legislation could be obtained giving advantages to the enlisted men of the Navy similar to those which the Army has had for several years."

2. When men are kept at sea continuously for a considerable time or located at remote stations where dental surgeons are inaccessible, it seems to us an inexcusable hardship, as the neglect of proper treatment for the teeth may ultimately result in great expense through pensions, besides the inhumanity and suffering which necessarily occur in the absence of prompt and scientific treatment of the teeth when needed. The charts or diagrams of some fifty or more particular cases represented to this committee from a single station at Newport, R. I., is ample proof of conditions which ought not to exist. One apprentice but 16 years of age, had lost every one of the teeth from his upper jaw; another, aged 18 years, exhibited cavities in his 14 upper teeth; another, aged 16 years, had lost practically all of his molar teeth, and the few remaining teeth were imperfect; another, aged 17 years, had lost 7 tecth, and another, aged 18 years, had lost 7 molar teeth. Several others of the 50 cases from 16 to 18 years of age, had lost from 3 to 6 teeth. It was said of these cases, in general, that they presented either ordinary cavities of decay; dead teeth; inflamed gums; chronic abscesses discharging pus in the mouth; pus-producing diseases of the teeth, gums, and underlying bone, or germ-laden foreign matter in contact with the gums and teeth. Such conditions cause gastric and intestinal disorders, impair vitality, and make one more susceptible to infectious diseases. Fxperts in dentistry inform us that, under present conditions, a large percentage of the cases exhibited from this one station must inevitably lose their teeth at an early age, which may render them pensionable under existing law.

Let us consider the subject under three heads: What do we want? Why do we want it? What is the best way of getting it? Oneness of aim does not imply identity of means. A cautious conservatism is the duty of the hour; conservatism in method, and cooperation and forebearance in thought and action. It is as natural and allowable that another man should differ in opinion with me as that I should differ with him, and if we are both sincere we should have mutual indulgence. 


\section{WIIT IS WANTED.}

We want a corps of dental surgeons in the U. S. Xavy assigned to such naval stations as would make their services available to the officers, enlisted men and apprentice boys of the naval and marine military service and training schools. With the Army dental corps established as a precellent (it is the thin edge of the wedge), the creation of a similar service in connection with the Navy should be readily accomplished. If the Government finds the dental corps an indispensable part of Army medical practice, should it not, at least, provide for dental treatment for the enlisted men of the Navr. especially those on foreign stations for a period of two or three years, and for those restricted in or deprived of their liberty? If the Government considers it necessary to employ surgeons, pharmacists and chaplains in the Navy, why does it not employ dentists?

\section{WITY IT IS WANTED.}

Not forgetting that military and naval hospitals nerer originated from the spirit of humanity, but have been born of sheer necessity, we want a eorps of dentists in the U. S. Navy for, we arcrue, not only humanitarian but economic reasons. We state. on the testimony of the Surgeon-General of the Army, that the enst of maintaining it will be small compared with the relief from suffering obtained and the greater efficiency of officers and men who have dental service. Moreover, it would prove an economical investment in the matter of hospital expense and pensions, as Dr. Marshall. Army dental surgeon, says: "In treating these lesions of the mouth, dysentery and diarrhea are cured in a few weeks, that without treating the oral cavity, would have required care for months;" and the Pension Office states that: "Luss of teeth from traumatism or seurvy constitutes of jtself a pensionable disability," and: "Diseases of the mouth (gums) and loss of teeth are aceepted as results of scurvy."

$A$ writer in the Medical Pecord states that it is no use to dose patients with medicine when many of them are constantly swallowing any quantity of germs from unclean tecth, and in many cases large amounts of pus from abscesses. Another writer tells this story:

On the mareh every man was his own dentist. Exercising that resourefulness which necessity brends, soldiers would plug cavities in aching teeth with tobaceo, cayenne pepper, rubber (seraped from waterproof sheets), anything calculated to cover or kill an exposed, throbbing nerve. Such treatment rarely proved effective. After tossing through sleepless nights, the swollen-faced victim would parade with the sick, take the operating chair (an empty biscuit box) and submit to the doctor's hug.

Writing about the South African War, an English dentist says :

It was necessary that the teeth of the soldier should be especialiy good. In the early days of the campaign, when volunteers were rejected on account of bad teeth, the War Offee was laughed to scorn. "We don't want to eat the Boers," was said derisively. No, but they had to eat something a lot tongher than human flesh, and hundreds of men have latterly been invalided home on account of bad teeth.

A writer in the Pacific Dental Gazette says:

At the Naval Academy our Government finds it necessary to employ a dental surgeon in crder to make good officers of cadets. Why is it not necessary to employ dental surgeons for them after they have left their alma mater and are thousands of miles from home?

Although the men enlisted for the naval service have, prisumably, sound teeth, yet there is suffering among them from rarious dental troubles owing largely to the fact that from the time of enlistment to the time of discharge (four years) they have little opportunity to secure the services of a dentist, and their pay is such that they are in no position to elgage qualified civilian dental surgeons.

Dr. Otto Hollinger, Chicago, says:

It was my good fortune to serve the United States Nary in the Spanish-American war as an ordinary sailor, and $I$ agree in the contention for dentists in the Navy and in the Army. When we were on board the flagship lancaster at key West, preparatory to going to Cuba, a marine came to me with an aching molar. I did not have any medicine or instruments with me, and I sent him to a surgeon, who found a third molar aching very badly. The surgeon thought that by extracting the third molar he would relieve the tcothache, but he broke the tooth off, and thinking the tooth was locked with the second molar, he extracted the second molar also, but the toothache was not stopped and he then extracted the first molar which also was decayed. There were three teeth lost, and the poor fellow was sent out to service, but he came back in about two weeks in a very bad condition and was sent to the hospital, placed under a general anesthetic, and the roots were taken out.

In the time of service, men should have attention given to aching teeth, and then when they come into port they should receive the best that the science can give, because these men are giving their best to the Government. Dr. Marshall's suggestions and statements in the course of time will perhaps be greatly modified, but as for belittling these men who are giving their lives for us for from thirteen to nineteen dollars a month, I do not think that the Fourth International Dental Congress should go on record as countenancing anything of the kind.

Medical Inspector Howard E. Ames, U. S. N., recently Senior Medical Officer at the Naval Academy, has given me the following regarding his experience and practice respecting the teeth in his naval career: 'The sad neglect of the teeth and the apparent wide ignorance of their use and value has caused so much suffering that he has always endeavored to prevent and correct the causes of such troubles. The number of sick days caused by defects in the tecth in the Navy would be surprising if known. The sacrifice of teeth by extraction that conld have been saved by the dentist is unknown. He has always when possible arranged with some dentist to attend the requirements of the crew in their tooth troubles, for which special rates were made in keeping with their pay. This was done to encourage the men whose pay is not sufficient to secure the services of a competent man, unless the conditions were explained, and also to prevent their falling into the hands of quacks.

In the Greely Relief Expedition the teeth of every member of the crew of the Bear were carefully examined and all defects remedied. The result was that not a man suffered from toothache, while on other ships trouble of the teeth occurred. On the U. S. S. Detroit he carried a dentist from Hong Kong. China, to Nagasaki, Japan, a distance of two thousand miles, to put the crew's teeth in order, and before the trip the dentist worked on the ship over a week and after he reached port a week's more work kept him busy.

It has been his habit when the ship is in port for anv length of time to carry out these ideas, and the result has been most satisfactory. Further, he is a strong advocate for the establishment of a Dental Corps to be maintained at each of our naval stations.

Rear Admiral Caspar F. Goodrich, U. S. N., in writ. ing of the Camp of Sanitation, League Island, says:

The wants of the men in one essential were specially sulp. plied, and on a scale novel to my experience. Surgeon hiddle 
interested himself so much in this matter that it was not possible to deny him, even had I been moved to do so. A tent was set apart near his dispensary and a competent dentist engaged who brought down his chair and engine and all other instruments of torture which a diabolical ingenuity has devised. His victims are like the sands of the sea, but happily sorrowing, they left the camp and went into the service every man jack of them sound in teeth. It goes without saying that a special schedule of prices was agreed on by which the men secured first class work at the lowest posible rates, and the dentist got lots of valuable experience.

Captain Howe, who possesses the double qualification of active service in South Africa as a combatant during the war and a licentiateship in dental surgery, says that hundreds of otherwise suitable recruits are rejected owing to defective tecth, which could be made serviceable at a relatively small cost and even when a man is accepted the state, as a rule, does nothing to conserve his teeth. Should a soldicr's teeth commence to decay nothing is done for them until they ache, and then they are extracted, the result being that when the Reserves are called up, as in 1898, many men are rejected because they have an insufficient number of teeth. The loss in the fighting strergth of the Army during the late campaign owing to bad tecth and complaints traceable thereto was so great that before the end of the war the Government had sent out twelve civil dental surgeons, the result being a marked success. A dental surgeon has been sent out to Somaliland for duty during the present campaign, and at home two dental surgeons are being employed temporarily in Iondon and in Aldershot, with most successful results. Captain Howe lays stress on the absolute necessity of a policy of conservatism of teeth during the whole of a man's sorvice and suggests a plan, including the appointment of a staff dental surgrem at the War Office, to secure the attainment of this object.

\section{IIOW TO OBTAIN IT.}

As to the best way of getting a dental corps in the Navy, first and foremost should be sought and obtained, if possible, the recommendation of the Navy Department. "With the recommendation of the Navy Department," says the committee of the National Dental Association, "it would be easy to secure legislation that would supply the Navy's need in the premises." That has now been given, so far as the Bureau of Medicine and Surgery is concerned, in these words of SurgeonGeneral Rixey: "The Bureau recommends that Congress be asked to provide for the employment of dentists to be stationed at the large stations at home and all the stations beyond the territorial limits of the United States."

Granted that the claim for a commissioned status has been worked out as a separate proposition in the bill offered in Congress, the bill must be carefully considered. in relation to the established order into which it must go, if enacted into law, and it must work in unison and harmony with naval practice, otherwise the achievement would be mischievous.

Let us adapt ourselves to the situation. The dental surgeons of the Army are assigned to stations in Cuba, Porto Rico, Alaska, the Philippines and the United States. Similar assignments could be made to naval stations if dentists were employed in the Navy, say, to Boston, Mass., Newport, R. I., Brooklyn, N. Y., Philadelphia, Pa., Washington, D. C., Annapolis, Md., Norfolk, Va., Havana, Cuba, Bremerton, Wash., San Francisco, Cal., Yokohama, Japan, Cavite, P. I.; also to Monterideo, Uruguay, and Villefrance, France, where the ships of the South Atlantic Squadron and the European Squadron, respectively, stay for some time. At the naval stations, where ships are laid up for repairs and receiving ships are located, large numbers of enlisted men are found who have time which could be utilizel by the dentist who may have the advantage of abundant room. Strange as it may seem, a naval vessel in these days is not at sea for more than a montl at a time, and naval ships spend fully as much time in port as they do in cruising. I gathered as the unanimous sentiment of medical officers and others of the Navy that there is no place for the dentist on sea-going vessels. Such vessels are provided with dental cases, each containing a set of forceps, elevators, excavators, engine burs, socket hanitle for burs, plastic filling instruments and high grale. gutta-percha. These are used by the surgeons and hospital stewards, some of wlom have taken courses in dentistry. Dr. Pike, of California, who is located nea ${ }^{\circ}$ Mare Island, has "had naval surgeons call for a list of materials and medicines to be used in relieving tho various pains emanating from the mouth."

Practically there is no room on ships for dental work, for chair, cabinet, engine, etc. If located in or near the "sicklay" the dentist could work on only bright days. As to living quarters there night be trouble.

Recognizing that the equipment of the general surgeon is not wholly adeguate to relieve the diseases incident to the mouth, teeth and jaws, Surgeon-General Rixey has provided a course of lectures in the Naval Medical School in Washington. These are on elementary dentistry and instruction in the treatment of ordinary dental troubles, including relief from suffering, the insertion of temporary fillings to protect teeth from further decay until a farorable opportunity can be secured for permanent work, and the extraction of teeth. This action, together with the policy of the Bureau of Medicine and Surgery for the employment of dentists, shows that the Navy Department realizes its responsibilities. My order for this duty was from the Secretary of the Navy and was in part as follows:

You will proceed to Washington, D. C. for the purpose of delivering lestures on the subjects of dental emergencies and the care of the teeth of the Navy personnel, on the first ansi second of April, 1907 before the Naval Medical School. On the completion of this temporary duty you will return to the Naval Academy, Annapolis, $M d$. and resunic your regular duties.

In conclusion, it is not so much to the facts presented to Congress in the report of its Naval Committee (which are disquieting enough, especially respecting the teeth of apprentice boys) to which attention is directed at this time, as it is to the intelligent manner in which members of the House advocated the appointment of dental surgeons for the Navy.

\section{DISCUSSION.}

DR. James MCMancs, Hartford, Conn., said that experience as a member of the committee of the Association with reference to getting these bills passed, has convinced him that if the members of the dental profession had been in greater unity, if they had taken a little trouble to look into the matter more carefully and closely, if they had been willing to listen to one, even though they differed with him, and had tried to reach a point where they would all work together, and had then gone before the Military Committee and the Naval Committee, with a plan carefully prepared, showing no feeling, they would have got much quicker action from Congress. He considered it a serious matter to go out log-rolling with the members of the House and members of the Senate to get certain things done. He feared that there has been too much of the political ele- 
ment in this matter, and that there has been too much effort on the part of men to get their ideas through, rather than to look for the humanitarian side of the question, as they should. Dr. Grady, he said, made some statements which surprised him very much, and other statements which he had read of. He alwavs supposed that there was an examining board, and that no one was accepted, either as a sailor or soldier, who did not have tolerably good teeth, and still the report giren out indicates that some of these fellows have no teeth at all. Dr. Grady, he continued, stated that ships remain at a port generally more than a few weeks at a time. While there are no facilities for doing dental work on board a ship, he thought that the dentists in the different ports could do all the work necessary, as was suggested by Dr. Grady. Dr. MreManus agreed with Dr. Grady that if this matter were presented to the public more clearly, and if the dentists throughout the country would work more in harmony, something could be done that would be good for the sailor and soldier as well as for the Government, and recognition of the dentist's status would come in due time; but to attempt to settle affairs as they are now, regulating the Army and Navy, to go before Congress and ask for certain things that will be in conflict with the law, is a very foolish move. Dr. Mclanus was pleased to learn that Dr. Grady had been asked to address the Nary surgeons on this question. That, he said, makes for the benefit of the dental profession before the public. It is well that the highest order of surgeons in the country, those of the Army and tho Navy, have asked a practicing dentist to address them and give them some information on the care of the mouth and teeth.

Dr. J. A. Boare. New York City, referred to a paper by Dr. Cronin, who has in charge seventy-five other physicians naking an examination of the school children in New York City, in which the statement is made that something like 50 per cent. of the preventable diseases were spared the children breause of the examinations made. Dr. Cronin told Dr. Bogue that he had sent out 40.000 cards to the parents of the children notifying them that their children were afflicted with diseases of the eye. the ear, the tonsils, or the teeth, and suggesting that these children be roferred to their family dentist or physician. Jle received 12,000 replies. Dr. Bogne felt that a very succinct statement of the conditions which Dr. Grady has shown could be made by medical men, showing what the results of those conditions are almost sure to be, and what proper treatment will do. Those things should be put before the legislators. They do not partake of politics or personalities, but they do partake of the humanitarian feeling. Dr. Bogue believed that a statement of the expense of treating the sick in the hospitals beculuse of dental diseases. and the amount of saring that might be marle, would present an economic feature which would also appeal to the lawmakers.

Dr. V. A. Latham, Chicago, pointed out that it is a very good thing to show lawmakers the necessity of the services of the physician and the dentist. Dr. Latham has liad some experience in dental work on ocean liners, and fecls that any one could meet the conditions made by the different changes of temperature, and which account for the need of the dentist. There is no one, she said, who has ever taken the continental trips but knows of the trouble travelers have with their mouths. Dr. Latham's experience with naval men and young follows in the naval reserve has been that men who have worked on gunboats complain bitterly of the need of a dental surgeon, more so, even, than in the Army.

Dr. F. I. Fossume, New York City, was in accord with the opinions expressed by Dr. Grady. Cooperation on the part of American dentists, he said, is absolutely necessary to accomplish any part of the purpose outlined by Dr. Grady. British medical men deal with the subject along the lines referred to, as far as patholocric conditions are concerned. In an editorial in the British IAclical Joumal, on the tecth of the nation, it was there pointed out how great a calamity befell the British Army in the South $\Lambda$ frican war in regard to the teeth of the soldiers. It referred to the laying up of the men with dental diseases, loss of teeth, finally their refusing to do duty on ac. count of the corsdition of the terth. There is only one thing to be feared, he said, and that is, educating medical men in dentistry. No dentist fails to realize the mechanical skill required and the many difficult, fine points of minor surgery that must be considered and understood to save teeth. Dr. Fossume suggested that if the American Medical Association, as a whole, will heed the work of the Section on Stomatology, and accept articles along the line suggested, especially regarding remedies proposed to save the teeth of the men of both Army and Navy, then the dental surgeon will be accepted and will be placed on a par with the rest of the officers in both Army and Navy.

Dr. Truman W. Brophy, Chicago, stated that he has had a little to do with soldiers in the National Guard, as an officer in the First Regiment of the Illinois National Guard. He found, to his surprise, that he was kept busy looking after the mouths of the men who had come direct from the cities. The First Regiment is made up of Chicago young men, and it would seem natural that they would look to the condition of their teeth and mouths before going to camp; but always, in camp, there is a great deal to be done, and, he said, there is no doubt about the desirability of having the plan suggested by Dr. Grady carried out. At the present time, in Spain, every man who enters the army as a surgeon must have taken a course of instruction in a school of dentistry. In England, a man who wishes to become a surgeon in the army must pass an examination on the subject of diseases of the teeth, and if he fails he must go to a dental hospital and take a course of intruction regarding such diseases before he can be admitted to the army as a general surgeon or assistant surgeon. This matter is being eonsidered by nearly all the, governments of Europe at the present time. In the International Dental Federation there is a department of Dental Surgery of the Armics and Navics of the World, and a great deal of good work is being done in that line. As a member of that body, Dr. Brophy was anxious to see the Section, with the endorsement of the general body, adopt resolutions along the line suggested by Dr. Grady, so that the legislators elect will see to it that the wishes of the people are carried out along this line.

I)r. M. I. Schamberg, New York City, agreed with Dr. Brophy that the vote of the Executive Council, or the delegates of the American Medical Association, would carry weight. The only question is whether this thing ought to be done at once. He believes that the great harm that came from the attempt made by those in charge of the work in the Army was that they went at it in almost too aggressive a fashion, using political means, to a great extent, so that those members of Congress who had to deal with it, viewed it from a really nercenary standpoint. They thought: Here are the dentists of this country trying to insinuate themselves into the Army. It was difficult for them to see anything in any way other than from a monetary standpoint. He would not approve of dental surgeons accepting anything short of a full commission in the Navy. While serving in Porto Rico as assistant surgeon in the U. S. Army prior to the institution of the dental corps, he was imprrssed with the fact that a man's standing in the Army depended much on himself; that the men who did the work would receive recognition. Therc were many contract surgeons down there that were severely criticised, and many who were accepted and entertained by their superior officers were looked on as regular Army surgeons. But, he said, suppose those officers were to remain in the Army for an indefinite period and were to become incapacitated for work? The government would not take care of them after that time, for the reason that no matter how good the service they had rendered, the law says that a contract surgron is employed for the period he is able to work, and is paid for that period, and at the termination of it he ceases to be connected with the Army and ceases to be taken care of by the Government, the same as a man who is employed to drive one of the mule trains. It is for that reason that Dr. Schamberg would not approve of any step toward the creation of a dental rorps composed of contract dental surgeons. It is far better, he said, to await some definite action in that direction in the Army, before taking this step to put a dental corps in the Navy.

Dr. E. S. Talbot, Chicago, saw no objection to passing a 
resolution recommending the governing body to take such action, but any action that would be taken by the national bocly would have to be submitted to the House of Delegates and they would rote on it. He did not think they would take any action on it at present, under the peculiar condition of things as they now exist. We tried it in the Army matter, in the same way, and they flatly refused to have anything to do with it.

Dr. Ricuiard Gradr, Annapolis, Md, referring to what he had quoted from the Congressional Record, ventured to sity that it was known to few dentists or medical men. Mr. lioss, chairman of the Committee on Naval Affairs, opened the subject by saying: "We have no dentists in the Navy to-day, and, as you know, our men are frequently on ships for a number of months. They go on a cruise for two or three years, and are away from where they could obtain the means of properly taking care of their teeth. The Army has a corps of dentists, but the Navy never has had a corps; and yet I think there is more reason why the Navy should have dentists than the Army, because the Army is continually on the land, whereas the Nary is on the sea." The statcments made by other Congressmen are founded on observation and experience and are entilled to consideration accordingly by dentists in endeavoring to obtain legislation. The startling report respecting the condition of the mouths and teeth of fifty boys in training at Newport, as given officially, must, he said, be regarded as unimpeachablc in its detail of facts, such as "one apprentice but 16 years of age had lost every one of the teeth from his upper jaw; another, aged 18, exhibited cavities in his 14 upper tecth; another, aged 16, had lost practically all of his molar tecth, and the remaining teeth were imperfect; another. aged 17 , had lost 7 teeth, ana another, aged 18 , had lost 7 molar teeth; and several others of the 50 boys, from 16 to 18 years of age, liad lost from 3 to 6 teeth;" but to his knowledge. Dr. Grady said, as may be verified by reference to the reports of the Surgeon General of the Navy, boys are rejected for defective teeth by surgeons of the Navy; and the requirements for admission of che Navy are four serviceable molars, to the Army 6 serviceable molars, and to the Naval Academy, at least eight oprosing molars, two on each side of each jaw. Of courco, dertists at times find serious deficiencies that surgeons overlook. Dr. Grady said that some Congressmen refrained from supporting the "rider" because they bclieved it incomplete:- "If we are to have dental surgeons as officers of the Navy to go on retired list and be appointed for life, the same as all other ollicers . . . ought we not to say so when we commence it?" One member argued that the paan injures the profession it aims to protect:- "The committee in providing for dental surgeons discriminates against $1 \mathrm{~h}(\mathrm{~m}$. . . . We ought to provide them on the same basis exactly as other assistant surgeons-appointed by the President and confirmed by the Senate." The measure was further jeopardized by another provision which it was elaimed would "give a premium on flunkeyism and sycophancy." The disposition was so antagonistic that the gentleman in charge of the bill said, "I am perfectly wihing that the words 'and revocable at the pleasure of the President' shall be eliminated," the congressional sentiment being that "it would be better to put the power of removal in the Medical Department of the Navy," just as "the Medical Department of the Army has charge of that." Dr. Grady hoped that as a result of the discussion and inquiries the medical and dental professions shall come to a better understanding on this question of dental surgeons for the Navy, and that those who really have the interests of the service and of the profession at heart may combine their efforts and make them effective, as a unit, in the enactment of a comprehensive measure, free from admitted defects or significant omissions, which shall be satisfactory to all parties, because promotive of the interests of all. It is probable, Dr. Grady said, that the effort to do something adequate for dental surgeons in the Army and Navy will be resumed at the next session of Congress.

After Dr. Grady had concluded, the Section on Stomatology unanimously arlopted a resolution that dental surgeons ought to be appointed to serve the officers and enlisted men of the Navy and Marine Corps.
The House of Delegates later endorsed the employment of dentists in the Navy in the following resolution: "Resolved, That it is the sense of this House of Delegates that the efforts of Surgeon-General P. M. Rixey to secure legislative authority for the employment of dentists in the U. S. Navy be approved, and that the Committee on Medical Legislation be instructed to exert such influence on Congress as in its judgment may be deemed wise in support of the measures making such provision." Sce Tile Jocrxal, page 2063, June 15, 1907.

\section{ERYSIPELAS.}

\section{A STATISTIGAL STUDY OF FIYE HLNDRED AND SIXTY- FOUR CASES.*}

L. NAPOLEON BOSTON, A.M., M.D.

Adjunct Professor of Medicine, Medico-Chirurgical College; Physician to the I'hiladelphia Hospital; Director of Laboratory for cliuical Research, American Hospital for Diseases of the Stomach.

$$
\text { AND }
$$

ALBERT ENGLES BLACKBURN, M.D.

Instructor in Medicine, Medico-Chirurgical College; Assistant I'hysician to l'hiladelphia IIospital; l'hysician Out-Patient Department of I'resbyterian IIospital. PHILADELPIIIA.

The data here offered are founded on an analysis of the records of cases of erysipelas treated in the Philadelphia Hospital during the past fire years. Many of the 564 records examined were found incomplete in certain particulars and the greatest number of cases that could be included in any one table was 548 , the smallest number 511. Whenever any question arose as to the classification of a certain case it was excluded from our statistics, the object being to obtain statistics that would be of value with reference to hospital treatment of e:ysipelas. The influences of season, age, sex, race and nationality are set forth in the accompanying tables. Furtice analyses were made with reference to the effect of pre-existing diseases and complications (with special reference to nephritis) on the mortality rate.

\section{SEASON.}

Season has long been recognized as a prominent predisposing factor in erysipelas, the greatest number of cases occurring during colu weather, and this is, in a mosure, expiained through the fact that men are more likely to suffer abrasions of the skin during the winter months.

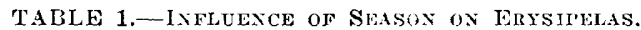

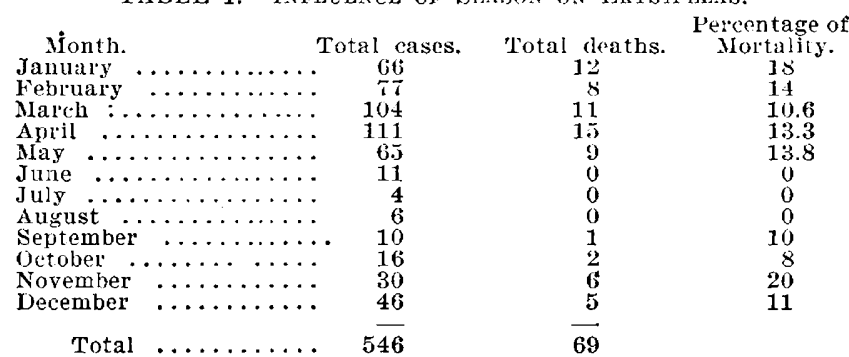

During June, July, August and Scptember, when in this climate we have our greatest heat, cases of erysipelas were few and, in fact, the rule is that during these months the erysipelas wards are often without a single occupant. Season also exerts a decided influence on the mortality rate, the greater proportionate number of deaths occurring during November, December, January and February, at which months, in this climate, we have

- Published through the courtesy of Dr. Joseph Neff, Director of Department of P'ublic Health and Charities, Philadelphia. 